\title{
A UPLC/DAD method for simultaneous determination of empagliflozin and three related substances in spiked human plasma
}

Mokhtar M. Mabrouk ${ }^{1,2}$, Suzan M. Soliman³ , Heba M. El-Agizy ${ }^{3}$ and Fotouh R. Mansour ${ }^{1,2^{*}}$

\begin{abstract}
A simple, rapid and sensitive ultrahigh performance liquid chromatographic method was developed for the determination of the anti-diabetic drug: empagliflozin (EMPA) and three related substances in spiked human plasma, using dapagliflozin (DAPA) as an internal standard and tetrahydrofuran as a plasma protein precipitating agent. The chromatographic separation was achieved on an Acquity "UPLC ${ }^{\circledR}$ BEH" 18 column $(50 \mathrm{~mm} \times 2.1 \mathrm{~mm}$ i.d, $1.7 \mu \mathrm{m}$ particle size), and a mobile phase consisting of aqueous trifluoroacetic acid $(0.1 \%, \mathrm{pH} 2.5)$ : acetonitrile $(60: 40, \mathrm{v} / \mathrm{v})$ at a flow rate of $0.5 \mathrm{~mL} / \mathrm{min}$. Upon using the UPLC system, the run time could be reduced to less than $1.2 \mathrm{~min}$, and the solvents consumption decreased to $0.36 \mathrm{~mL}$ of acetonitrile per run. The response was linear over a concentration range of $50-700 \mathrm{ng} / \mathrm{mL}$ and $40-200 \mathrm{ng} / \mathrm{mL}\left(\mathrm{r}^{2}=0.9994-0.9999\right)$ with lower limits of detection and quantification (LOD/LOQ) of $15 / 50,11.5 / 40,12 / 40$ and $12.5 / 40 \mathrm{ng} / \mathrm{mL}$ for EMPA and the three related substances, respectively. Good accuracy was obtained with mean percentage recoveries $\geq 96.97 \%$ for the studied compounds. The method was validated according to the ICH guidelines and was found suitable for routine analysis of EMPA and its related substances in human plasma
\end{abstract}

Keywords: Empagliflozin, Related substances, UPLC, Spiked human plasma, THF protein precipitation

\section{Introduction}

Empagliflozin (EMPA) is a new oral antidiabetic drug, prescribed mainly for the treatment of type 2 diabetes. EMPA works by selective inhibition of sodium glucose cotransporter-2 (SGLT-2) [1]. The new pharmacological class of SGLT2-inhibitors lower blood glucose levels by targeting the kidney, reducing renal glucose reabsorption, and increasing urinary glucose elimination [2]. Determination of EMPA in bulk and/or pharmaceutical dosage forms as well as in human plasma has been reported in a few methods using spectrophotometric techniques [3, 4] and liquid chromatography [5-21]. Related substances are either produced as impurities from the manufacturing process, degradation products from improper storage

\footnotetext{
*Correspondence: fotouhrashed@pharm.tanta.edu.eg

1 Department of Pharmaceutical Analytical Chemistry, Faculty

of Pharmacy, Tanta University, Elgeish Street, Medical Campus,

Tanta 31111, Egypt

Full list of author information is available at the end of the article
}

or as metabolites that are either active, inactive or even toxic [22].

The present study is interested in analysis of EMPA and three EMPA related substances (ERSs) that result from ring opening (ERS1), isomerization (ERS2) and alkylation/ring size reduction (ERS3). Figure 1 shows the chemical structure of EMPA and the related substances (ERS1-3). In spite of the many analytical techniques used for analysis of EMPA either alone [5-9] or in combination with other co-formulated drugs [10-18] and the available pharmacokinetic studies in literature [19-21], there are no analytical methods available with full details regarding plasma extraction and determination of EMPA and its three related substances in plasma samples to evaluate the pharmacokinetic parameters of the studied compounds. To the best of our knowledge, the present analysis is the first UPLC method carried out for the simultaneous determination of EMPA and these related substances in human plasma. The aim of this work is to develop a simple, fast, sensitive and fully validated 
<smiles>OC[C@H]1O[C@@H](c2ccc(Cl)c(Cc3ccc(O[C@H]4CCOC4)cc3)c2)[C@H](O)[C@H](O)[C@@H]1O</smiles>

Empagiflozin<smiles>OC[C@@H](O)[C@@H](O)[C@@H](O)[C@H](O)C(O)c1ccc(Cl)c(Cc2ccc(O[C@H]3CCOC3)cc2)c1</smiles>

EMPA related substance 1<smiles>OC[C@H]1O[C@@H](c2ccc(Cl)c(Cc3ccc(O[C@H]4CCOC4)cc3)c2)[C@H](O)[C@H](O)[C@@H]1O</smiles>

EMPA related substance 2<smiles>COC1(c2ccc(Cl)c(Cc3ccc(OC4CCOC4)cc3)c2)O[C@H]([C@H](O)CO)[C@@H](O)[C@H]1O</smiles>

EMPA related substance 3<smiles>CCOc1ccc(Cc2cc([C@@H]3O[C@H](CO)[C@@H](O)[C@H](O)C3O)ccc2Cl)cc1</smiles>

Dapagliflozin (IS)

Fig. 1 Chemical structures of empagliflozin (EMPA), its three related substances (ERS1-3) and dapagliflozin (DAPA) (IS)

UPLC/DAD method for separation and quantitation of EMPA and the three related substances using dapagliflozin (DAPA) as an internal standard.

\section{Experimental}

\section{Instruments}

Chromatographic separation was carried out on an ACQUITY UPLC system (Waters Corp., Milford, MA, USA). The UPLC was equipped with a quaternary solvent manager SN C15QSM334A ver 1.65.287 and a temperature-controlled autosampler SN C155DI089G ver 1.65.375, coupled to a DAD detector SN C15UPL193A ver 1.65.6229 and connected to Waters Empower 2 software.

\section{Materials and reagents}

Empagliflozin standard sample and its three related substances were kindly provided by Boehringer Ingelheim (Ingelheim, Germany), with $99.98 \%$ purity for the drug, based on the company analysis certificate. DAPA propanediol monohydrate was kindly supplied by AstraZeneca (Giza, Egypt) and was used as an internal standard (IS).
DAPA purity was found to be $99.59 \%$. Acetonitrile and methanol (HPLC grade) were purchased from J.T.Baker (Phillipsburg, NJ, USA) and Fischer Chemical (Loughborough, UK), respectively. Tetrahydrofuran (THF) and trifluoroacetic acid were purchased from Sigma-Aldrich (St. Louis, MO, USA) and Carlo Erba reagents (Peypin, France), respectively. Deionized water was obtained from a Milli-Q water purification system (Millipore, USA). Human plasma samples were kindly supplied from Vacsera National Blood Bank, Egypt, frozen until use after gentle thawing.

\section{Chromatographic conditions}

Separation of the analytes was performed on an Acquity UPLC $^{\circledR}$ BEH C18 column $(50 \mathrm{~mm} \times 2.1 \mathrm{~mm}$ i.d, $1.7 \mu \mathrm{m}$, Waters Corp., USA); the column oven temperature was maintained at $50{ }^{\circ} \mathrm{C}$. The samples were eluted with an isocratic mobile phase consisting of acetonitrile-aqueous $0.1 \%$ trifluoroacetic acid $\mathrm{pH} 2.5,(40: 60, v / v), \mathrm{pH}$ was adjusted to $\mathrm{pH} 2.5$ with glacial acetic acid. The flow rate was $0.5 \mathrm{~mL} / \mathrm{min}$ and the injection volume was $5 \mu \mathrm{L}$. The response of the photodiode array detector (DAD) 
over the range $200-400 \mathrm{~nm}$ was studied. Detection and quantitation of the analytes were performed at optimum intensity of $\lambda 210 \mathrm{~nm}$ (Fig. 2).

\section{Preparation of standard solutions}

Stock solutions of EMPA $(100 \mu \mathrm{g} / \mathrm{mL})$, each of the related substances $(400 \mu \mathrm{g} / \mathrm{mL})$ and DAPA $(1000 \mu \mathrm{g} / \mathrm{mL})$ were prepared in the mobile phase and stored at $4{ }^{\circ} \mathrm{C}$ until use. The working solutions were freshly prepared by the appropriate dilution of the stock solutions with the mobile phase to obtain $5 \mu \mathrm{g} / \mathrm{mL}$ of DAPA in each solution as an internal standard with EMPA in the range $50-700 \mathrm{ng} / \mathrm{mL}$ and ERS in the range $40-200 \mathrm{ng} / \mathrm{mL}$. All solutions were stored at $2-8{ }^{\circ} \mathrm{C}$ and brought to room temperature before use.

\section{Plasma samples preparation}

After thawing the samples at room temperature, $10 \mu \mathrm{L}$ of the IS solution was added in each tube and the sample was vortexed for $30 \mathrm{~s}$. After that, $1 \mathrm{~mL}$ of THF was added to an aliquot containing plasma, EMPA, ERS1, ERS2, ERS3 and IS. The mixture was mixed again, vortexed and then centrifuged at $4000 \mathrm{rpm}$ for $5 \mathrm{~min}$; the supernatant was filtered through a $0.2 \mu \mathrm{m}$ syringe filter and carefully transferred into a UPLC vial and $5 \mu \mathrm{L}$ were injected into the UPLC system.

Calibration curves were constructed from a blank sample (a plasma sample without the IS), a zero sample (a plasma spiked with the IS) and non-zero samples covering the total range of $50-700 \mathrm{ng} / \mathrm{mL}$ and $40-200 \mathrm{ng} / \mathrm{mL}$ for EMPA and its three related substances, respectively; including the lower limit of quantification (LLOQ). The concentrations of the drug and its related substances were determined using the corresponding regression equations. The samples were stored in a freezer at $-20{ }^{\circ} \mathrm{C}$ until analysis, and then allowed to thaw at $25{ }^{\circ} \mathrm{C}$ before processing. The plasma samples were centrifuged at $4000 \mathrm{rpm}$ for $5 \mathrm{~min}$, for each concentration.

\section{Stability of EMPA in human plasma}

The acceptable stability of the analytes in spiked plasma during sample storage and during processing conditions was investigated by analyzing the drug at five levels: lower limit of quantitation (LLOQ, $50 \mathrm{ng} / \mathrm{mL}$ ), low quality control (LQC, $100 \mathrm{ng} / \mathrm{mL}$ ), medium quality control (MQC, $300 \mathrm{ng} / \mathrm{mL}$ ), high quality control (HQC, $500 \mathrm{ng} /$ $\mathrm{mL}$ ) and upper limit of quantitation (ULOQ, $700 \mathrm{ng} / \mathrm{mL}$ ) and the results were compared with that of zero cycles. The short-term stability (bench-top stability) was determined after sample storage at room temperature for $24 \mathrm{~h}$, freeze-thaw stability was determined over three freeze-thaw cycles within 3 days. In each cycle, the frozen plasma samples were thawed at room temperature for $2 \mathrm{~h}$ and refrozen for $24 \mathrm{~h}$. The long-term stability was determined at the same five QC levels $(50,100,300$, 500 and $700 \mathrm{ng} / \mathrm{mL}$ ) after sample storage at $-20{ }^{\circ} \mathrm{C}$ for 30 days. The concentration of EMPA after each storage period was related to the initial concentration at zero cycle (samples that were freshly prepared and processed immediately). The samples were considered stable if the deviation (expressed as percentage bias) from the zero cycle was within $15 \%$.

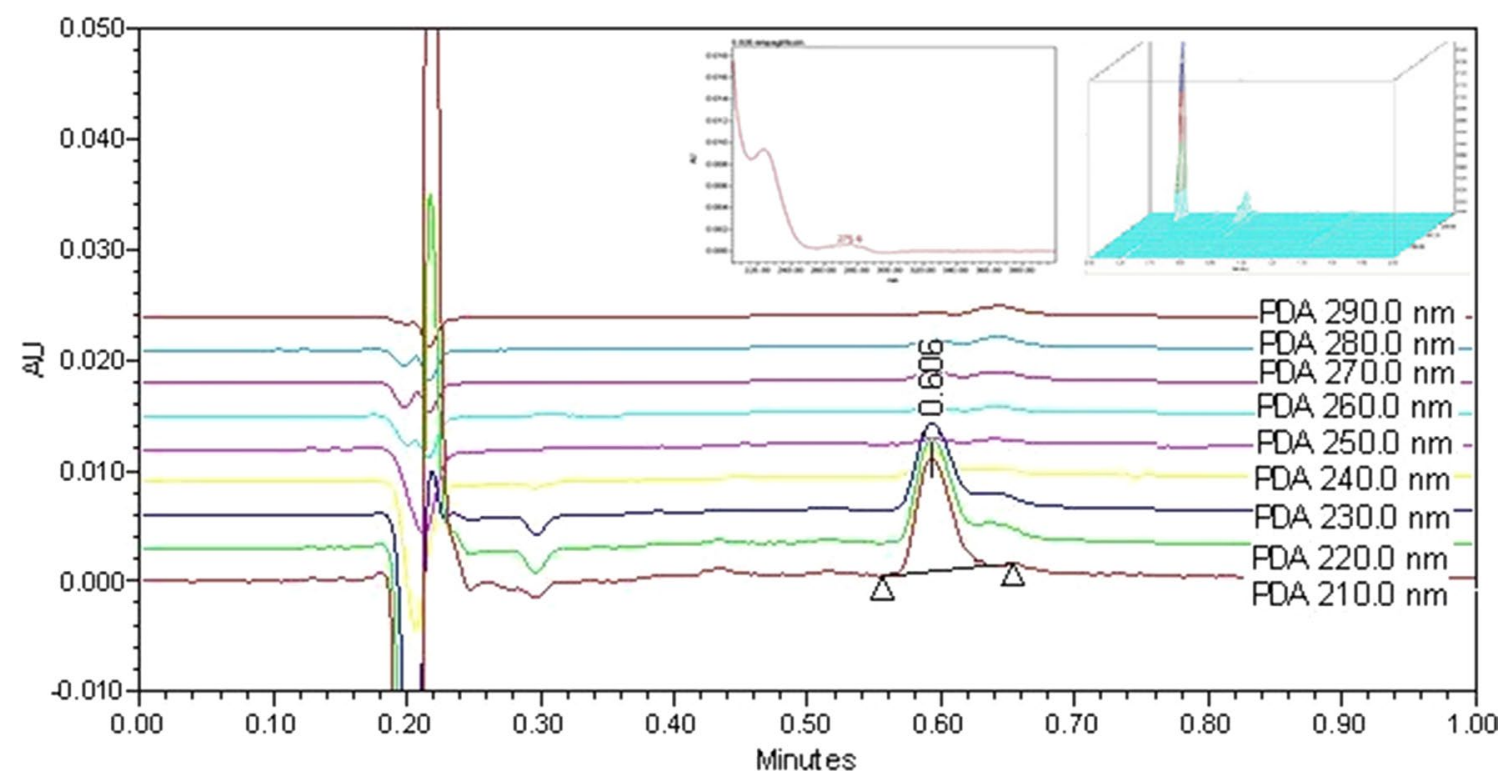

Fig. 2 An overlay of EMPA chromatograms at different wavelengths (210-290 nm) 


\section{Results and discussion}

Empagliflozin is orally active with a $78 \%$ bioavailability after a single oral dose [23]. The peak plasma concentrations of EMPA is reached at $1.5 \mathrm{~h}$ post-dose. EMPA plasma concentrations decline in a biphasic manner with a rapid distribution phase and a relatively slow terminal phase. The steady state mean plasma AUC and $\mathrm{C}_{\max }$ are $843.2 \mathrm{ng} \mathrm{h} / \mathrm{mL}$ and $116.8 \mathrm{ng} / \mathrm{mL}$, respectively, with $10 \mathrm{mg}$ EMPA once daily treatment [23].

\section{Method development and optimization}

Since EMPA is highly bound to plasma proteins [24], protein precipitation by a suitable precipitating agent is crucial to denature the plasma proteins and liberate the free drug. Three different protein precipitants were tried including acetonitrile, methanol and tetrahydrofuran in 1:1 ratio (plasma:precipitating agent, $\mathrm{v} / \mathrm{v}$ ). The peak intensity of EMPA and the baseline drift were compared. Tetrahydrofuran was found to give the highest peak intensity and the most stable baseline.

To correct for sample loss during preparation, an internal standard was added. Several drugs were tested,
DAPA which is structurally related to EMPA drug and possess an ethyl group in place of the oxolane moiety, was selected as the appropriate IS, giving an acceptable retention time with a symmetrical peak shape (Fig. 3).

Increasing the sensitivity and the selectivity of the developed method have been taken into consideration during method development by optimizing detection wavelength, $\mathrm{pH}$ of the aqueous portion of the mobile phase, percentage of acetonitrile in the mobile phase, the diluting solvent and the column temperature before analysis.

The effect of different $\mathrm{pH}$ values in the mobile phase were carefully studied at $\mathrm{pH} 2.5,3.5$ and 4.5. Although the elution of EMPA and DAPA peaks seemed to happen a bit earlier in $\mathrm{pH} 3.5$ and 4.5 than in case of $\mathrm{pH} 2.5$ (Additional file 1: Fig. S1) but the peak areas decreased with increasing $\mathrm{pH}$. A mobile phase $\mathrm{pH}$ of 2.5 was selected to attain a chromatogram with high peak areas, optimum resolution, and a less drifty baseline.

Percentages of acetonitrile in the mobile phase were studied using three different ratios (20:80, 30:70 and $40: 60, v / v$ of acetonitrile-aqueous $0.1 \%$ trifluoroacetic acid $\mathrm{pH} 2.5$ ). The ratio 40:60 with a flow rate of $0.5 \mathrm{~mL} /$
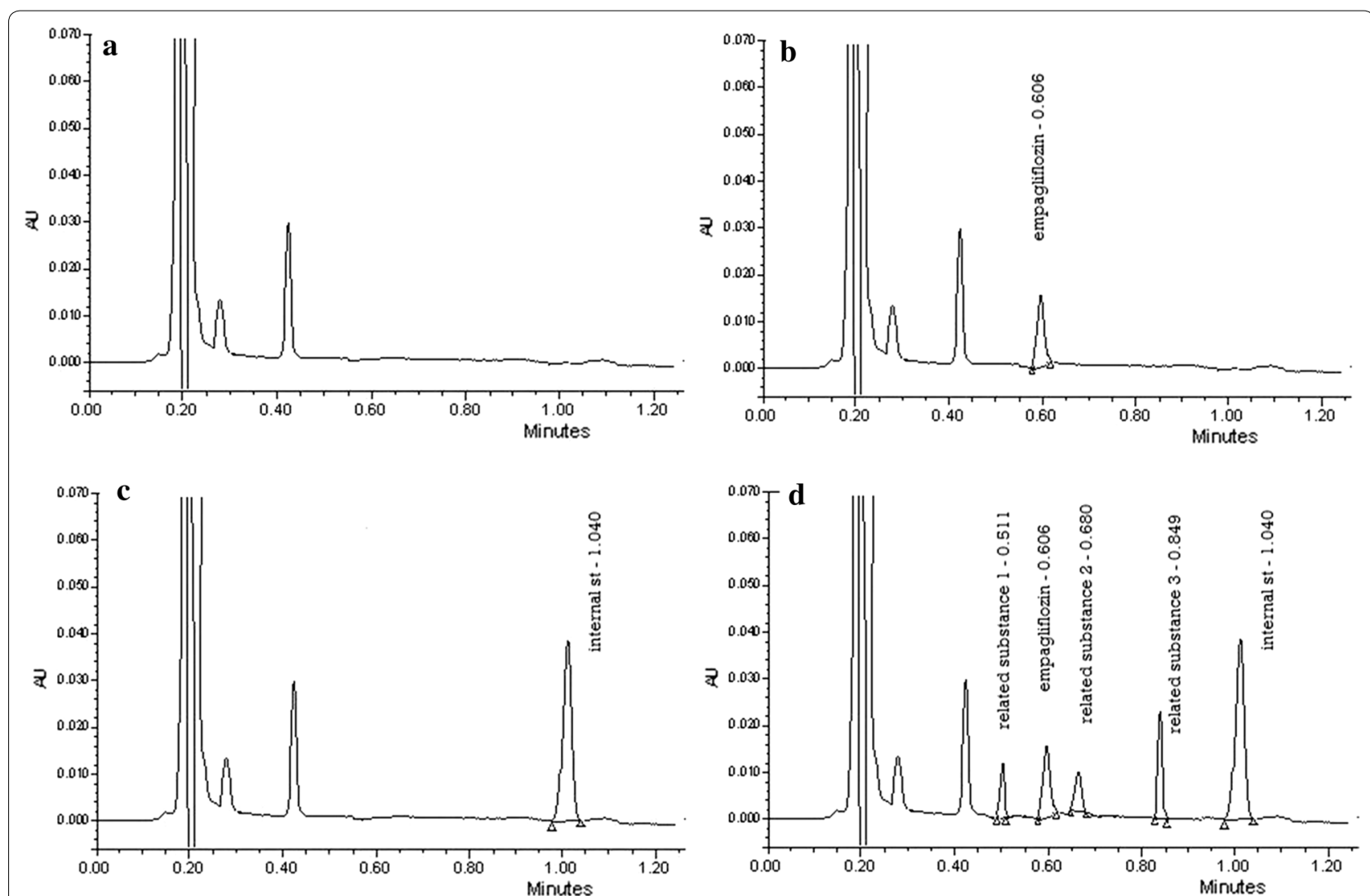

Fig. 3 Chromatograms of a blank plasma, b plasma spiked with $700 \mathrm{ng} / \mathrm{mL}$ EMPA, c plasma spiked with 5 $\mu \mathrm{g} / \mathrm{mL}$ I.S, d plasma spiked with $700 \mathrm{ng} /$ $\mathrm{mL}$ EMPA, $200 \mathrm{ng} / \mathrm{mL}$ of each related substance and $5 \mu \mathrm{g} / \mathrm{mL}$ is 
min achieved the highest peak areas and the fastest elution as well (Additional file 1: Fig. S2).

The solvent, used for dilution, had a great influence on peaks' shape, area and retention times. Upon using pure methanol as a diluting solvent, the peaks of drug and IS were neither sharp nor symmetric and a huge solvent peak were observed in the chromatogram, while on using water-methanol $(50: 50, \mathrm{v} / \mathrm{v})$ the peaks of the analytes were improved in shape but a huge solvent peak was observed. This problem was diminished by using the mobile phase as a diluting solvent (Additional file 1: Fig. S3).

Column temperature was assessed by using three different column oven temperatures: 30,40 and $50{ }^{\circ} \mathrm{C}$, a very poor peak shape and area were obtained at low temperatures $\left(\leq 40{ }^{\circ} \mathrm{C}\right)$, increasing column oven temperature to $50^{\circ} \mathrm{C}$ greatly enhanced both shape and intensity of the peaks (Additional file 1: Fig. S4). The optimum separation was achieved using an isocratic mobile phase consisting of acetonitrile: trifluoroacetic acid $(0.1 \%, \mathrm{pH} 2.5)$ (40:60, $v / v)$, at a flow rate of $0.5 \mathrm{~mL} / \mathrm{min}$ and an injection volume of $5 \mu \mathrm{L}$ and a column temperature of $50^{\circ} \mathrm{C}$.

System suitability was assessed by calculating capacity factor $\left(-k^{\prime}\right)$, selectivity $(\alpha)$, resolution $\left(R_{s}\right)$, tailing factor $(\mathrm{T})$, and number of theoretical plates $(\mathrm{N})$, where the system was found to be suitable for the intended purpose under the specified conditions (Table 1).

Table 1 System suitability parameters by the proposed UPLC method

\begin{tabular}{lllllll}
\hline Parameters & ERS1 & EMPA & ERS2 & ERS3 & IS & Recommended value $^{\text {a }}$ \\
\hline Retention time & 0.511 & 0.606 & 0.68 & 0.849 & 1.040 & - \\
$-k^{\prime}$ & 1.55 & 2.12 & 2.49 & 3.26 & 4.39 & $1-10$ acceptable \\
$a$ & - & 1.37 & 1.17 & 1.31 & 1.76 & $>1$ \\
$\mathrm{R}_{\mathrm{s}}$ & - & 2.15 & 2.01 & 5.51 & 7.81 & $>2$ \\
$\mathrm{~T}$ & 0.95 & 1.01 & 1.05 & 0.98 & 1.3 & $\leq 2$ \\
$\mathrm{~N}$ & 12,890 & 3920 & 4023 & 13,205 & 4527 & 2000-10,000 increases with \\
& & & & & & efficiency of the separation \\
\hline
\end{tabular}

a Values defined by FDA Center of Drug Evaluation and Research's reviewer guidance on validation of chromatographic methods [25]

Table 2 Validation parameters of the proposed UPLC method for the determination of EMPA and its three related substances in spiked human plasma

\begin{tabular}{|c|c|c|c|c|}
\hline Parameter & $\begin{array}{l}\text { EMPA in spiked human } \\
\text { plasma }\end{array}$ & ERS1 & ERS2 & ERS3 \\
\hline Range (ng/mL) & $50-700$ & $40-200$ & $40-200$ & $40-200$ \\
\hline$n$ & 8 & 5 & 5 & 5 \\
\hline $\operatorname{LOD}(\mathrm{ng} / \mathrm{mL})^{\mathrm{a}}$ & 15 & 11.5 & 12 & 12.5 \\
\hline $\operatorname{LLOQ}(\mathrm{ng} / \mathrm{mL})^{b}$ & 50 & 40 & 40 & 40 \\
\hline \multicolumn{5}{|l|}{ Accuracy } \\
\hline Intra-day ${ }^{c}$ & 97.09 & 97.86 & 99.28 & 96.97 \\
\hline Inter-day ${ }^{d}$ & 98.18 & 99.47 & 98.20 & 99.67 \\
\hline \multicolumn{5}{|l|}{ Precision $\pm \%$ RSD } \\
\hline Intra-day ${ }^{c}$ & \pm 6.38 & \pm 7.26 & \pm 7.94 & \pm 7.34 \\
\hline Inter-day ${ }^{d}$ & \pm 6.63 & \pm 7.93 & \pm 6.60 & \pm 7.42 \\
\hline \multicolumn{5}{|l|}{ Linearity } \\
\hline Slope & 0.0003 & 0.0002 & 0.0005 & 0.0007 \\
\hline Standard deviation of slope & $5.7 \times 10^{-6}$ & $5.8 \times 10^{-6}$ & $7.6 \times 10^{-6}$ & $6.8 \times 10^{-6}$ \\
\hline Intercept & -0.0016 & -0.0008 & -0.0004 & -0.0032 \\
\hline Standard deviation of intercept & 0.00001 & 0.00002 & 0.00001 & 0.00007 \\
\hline Correlation coefficient (r) & 0.9999 & 0.9994 & 0.9999 & 0.9997 \\
\hline
\end{tabular}

a LOD is the lowest detectable amount of the selected drug that could be detected

b LLOQ is the lowest concentration of the analyte that can be measured accurately under the proposed experimental condition

c The intra-day study was performed for five concentrations for EMPA and its related substances (ERS 1-3), repeated three times within the day

$d$ The inter-day study was performed for five concentrations for EMPA and its related substance (ERS 1-3), repeated three times in 3 successive days 


\section{Method validation}

The validity of the method was assessed for linearity, specificity, accuracy, repeatability, recovery and precision according to the $\mathrm{ICH}$ bio-analytical method validation guidelines [25].

A calibration curve was constructed by plotting the ratio of peak areas (drug/IS) against concentration of the analyte in the plasma. Standard calibration curves exhibited good linearity over the concentration range 50-700 ng/mL for EMPA and 40-200 ng/mL for the three related substances, with good correlation coefficient and regression data as shown in Table 2.

The limit of detection (LOD) is defined as the lowest detectable amount of the selected drug that could be detected, while lower limit of quantification (LLOQ) is the lowest concentration of the analyte that can be measured accurately and precisely under the proposed experimental conditions. LLOQ should meet the acceptable criteria (precision $= \pm 20 \%$ and the accuracy within $80-120 \%)$. The values of the LLOQ were $50 \mathrm{ng} / \mathrm{mL}$ and $40 \mathrm{ng} / \mathrm{mL}$ for EMPA and the three ERSs, respectively (Table 2).
Accuracy and precision were evaluated by analysis of quality control samples in the range $50-700 \mathrm{ng} / \mathrm{mL}$ for EMPA and 40-200 ng/mL for EMPA related substances, using three determinations per concentration on 3 consecutive days. The accuracy was expressed as \%recovery while the precision was monitored by the \%RSD. Table 3 summarizes the results of accuracy and precision for the intra- and inter-day analysis of the analytes in plasma. The proposed UPLC method was able to determine different concentrations of EMPA over the working concentration range with \%RSD less than $15 \%$.

The selectivity of the method was assessed by analyzing six different batches of human plasma to check for interference from endogenous substances. In addition, the peak purity of EMPA was checked by using a DAD detector. The calculated purity angle (35.89) was found to be less than the purity threshold (90) which demonstrates the homogeneity of the analyte peak and indicates that it had passed the peak purity test, as illustrated in Fig. 4.

Robustness of the method was assessed by undergoing minor changes in the experimental parameters such as, changing the volume of acetonitrile $\pm 2 \mathrm{~mL}, \mathrm{pH} \pm 0$.

Table 3 Recovery and precision of EMPA and its related substances

\begin{tabular}{|c|c|c|c|c|c|c|c|}
\hline \multirow[t]{2}{*}{ Compound } & \multirow[t]{2}{*}{$\begin{array}{l}\text { Concentration } \\
\text { added (ng/mL) }\end{array}$} & \multicolumn{3}{|l|}{$\begin{array}{l}\text { Intra-day\% } \\
(n=5)\end{array}$} & \multicolumn{3}{|l|}{$\begin{array}{l}\text { Inter-day\% } \\
(n=5)\end{array}$} \\
\hline & & $\begin{array}{l}\text { Concentration } \\
\text { found }(\mathrm{ng} / \mathrm{mL})\end{array}$ & $\begin{array}{l}\text { Recovery \% } \\
(n=5)\end{array}$ & $\%$ RSD & $\begin{array}{l}\text { Concentration } \\
\text { found }(\mathrm{ng} / \mathrm{mL})\end{array}$ & $\begin{array}{l}\text { Recovery \% } \\
(n=5)\end{array}$ & \%RSD \\
\hline \multirow[t]{5}{*}{ EMPA } & 50 (LLOQ) & 46.21 & 92.42 & 13.8 & 47.15 & 94.30 & 11.1 \\
\hline & 100 (LQC) & 98.60 & 98.60 & 4.34 & 96.22 & 96.22 & 6.38 \\
\hline & 300 (MQC) & 293.79 & 97.93 & 5.90 & 301.7 & 100.6 & 9.45 \\
\hline & $500(\mathrm{HQC})$ & 501.36 & 100.27 & 4.22 & 494.3 & 98.86 & 3.61 \\
\hline & 700 (ULOQ) & 673.54 & 96.22 & 3.67 & 706.5 & 100.9 & 2.59 \\
\hline Mean & & & 97.09 & 6.38 & & 98.18 & 6.63 \\
\hline \multirow[t]{5}{*}{ ERS1 } & 40 (LLOQ) & 36.19 & 90.48 & 11.9 & 43.71 & 109.3 & 12.4 \\
\hline & 80 (LQC) & 84.48 & 105.6 & 6.76 & 75.98 & 94.98 & 9.11 \\
\hline & 120 (MQC) & 114.6 & 95.50 & 8.42 & 110.7 & 92.25 & 8.92 \\
\hline & 160 (HQC) & 154.9 & 96.84 & 3.90 & 156.2 & 97.63 & 4.15 \\
\hline & 200 (ULOQ) & 201.7 & 100.9 & 5.32 & 206.3 & 103.2 & 5.07 \\
\hline Mean & & & 97.86 & 7.26 & & 99.47 & 7.93 \\
\hline \multirow[t]{5}{*}{ ERS2 } & 40 (LLOQ) & 36.68 & 91.70 & 13.2 & 35.82 & 89.55 & 14.3 \\
\hline & 80 (LQC) & 77.86 & 97.33 & 5.92 & 75.37 & 94.21 & 7.05 \\
\hline & 120 (MQC) & 125.5 & 104.6 & 7.09 & 118.6 & 98.83 & 2.64 \\
\hline & 160 (HQC) & 164.6 & 102.9 & 6.39 & 169.4 & 105.9 & 6.08 \\
\hline & 200 (ULOQ) & 199.7 & 99.85 & 7.11 & 204.9 & 102.5 & 2.94 \\
\hline Mean & & & 99.28 & 7.94 & & 98.20 & 6.60 \\
\hline \multirow[t]{5}{*}{ ERS3 } & 40 (LLOQ) & 37.72 & 94.30 & 14.6 & 38.70 & 96.75 & 12.9 \\
\hline & 80 (LQC) & 81.68 & 102.1 & 9.63 & 79.11 & 98.89 & 10.3 \\
\hline & 120 (MQC) & 111.7 & 93.08 & 6.37 & 122.9 & 102.4 & 7.25 \\
\hline & 160 (HQC) & 154.9 & 97.34 & 4.08 & 164.3 & 102.7 & 3.69 \\
\hline & 200 (ULOQ) & 196.1 & 98.05 & 2.01 & 195.2 & 97.60 & 2.98 \\
\hline Mean & & & 96.97 & 7.34 & & 99.67 & 7.42 \\
\hline
\end{tabular}




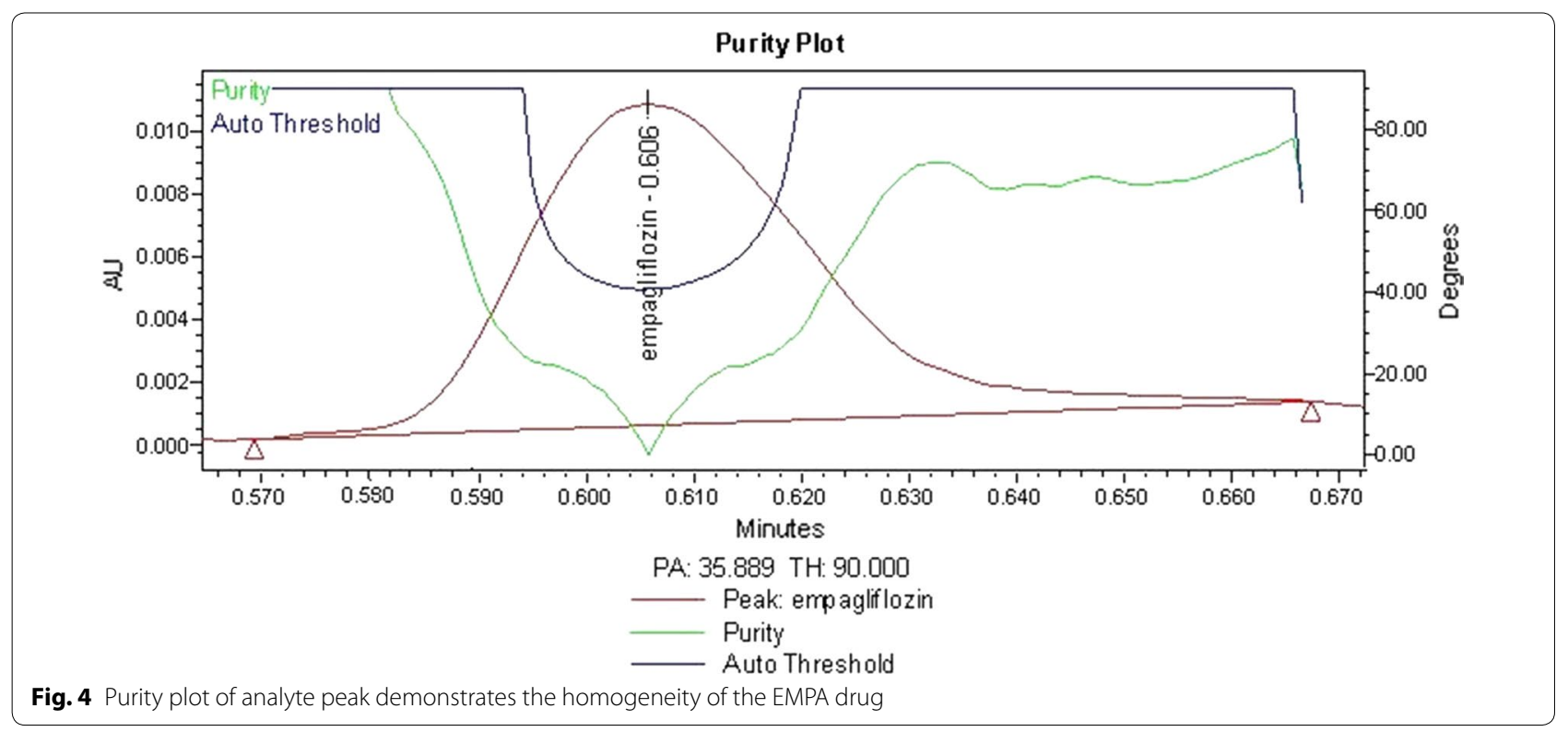

Table 4 Stability of EMPA in human plasma

\begin{tabular}{|c|c|c|c|c|}
\hline Parameters & Concentration (ng/mL) & \%Recovery & \%RSD & \%RE \\
\hline \multirow{5}{*}{$\begin{array}{l}\text { Short term } \\
\text { At } 25^{\circ} \mathrm{C}, 24 \mathrm{~h}\end{array}$} & 50 (LLOQ) & 95.37 & 13.5 & -4.63 \\
\hline & 100 (LQC) & 104.1 & 10.9 & 4.10 \\
\hline & 300 (MQC) & 93.71 & 9.62 & -6.29 \\
\hline & $500(\mathrm{HQC})$ & 101.5 & 8.07 & 1.50 \\
\hline & 700 (ULOQ) & 99.01 & 4.39 & -0.99 \\
\hline \multirow{5}{*}{$\begin{array}{l}\text { Long term } \\
\text { At }-20^{\circ} \mathrm{C}, 30 \text { days }\end{array}$} & 50 (LLOQ) & 90.63 & 11.2 & -9.37 \\
\hline & 100 (LQC) & 93.82 & 7.37 & -6.18 \\
\hline & 300 (MQC) & 95.13 & 5.97 & -4.87 \\
\hline & $500(\mathrm{HQC})$ & 103.7 & 7.11 & 3.68 \\
\hline & 700 (ULOQ) & 108.4 & 8.94 & 8.42 \\
\hline \multirow{5}{*}{$\begin{array}{l}\text { Three freeze-thaw cycles thawed at } 25^{\circ} \mathrm{C} \text { for } \\
2 \mathrm{~h} \text {, refrozen } 24 \mathrm{~h}\end{array}$} & 50 (LLOQ) & 92.07 & 12.9 & -7.93 \\
\hline & 100 (LQC) & 101.7 & 8.66 & 1.70 \\
\hline & 300 (MQC) & 91.91 & 10.1 & -8.09 \\
\hline & $500(\mathrm{HQC})$ & 93.44 & 9.79 & -6.56 \\
\hline & 700 (ULOQ) & 97.12 & 4.64 & -2.88 \\
\hline
\end{tabular}

2, column temperature $\pm 2{ }^{\circ} \mathrm{C}$ and wavelength $\pm 2 \mathrm{~nm}$. These minor changes that may take place during the experimental operation did not significantly affect the peak area values of the analytes.

The stability of the analyte in plasma was assessed at varying stability conditions. The samples were analyzed and the results were compared with that obtained with the corresponding freshly prepared and immediately processed samples. EMPA showed stability in spiked human plasma when stored at ambient temperature for at least $24 \mathrm{~h}$, also when stored at $-20{ }^{\circ} \mathrm{C}$ for 1 month as longterm stability, and over three freeze-thaw cycles. The results indicate reliable stability during analysis and no stability-related problems during bio-analytical studies (Table 4).

\section{Conclusion}

A novel, fast, sensitive, selective and fully validated UPLC/DAD method was developed for analysis of EMPA and its three related substances in spiked human plasma. Favorable advantages of the proposed UPLC method were found in significant reduction in elution time as well as simplicity of sample preparation and minimization 
of solvent consumption when compared with other reported methods. Moreover, THF is a new plasma protein-precipitating agent that has the advantages of being cheap, efficient and suitable for drugs which are insoluble in common organic solvents. Owing to the short run time (1.2 min), rapid analysis of hundreds of plasma samples per day was possible, which makes the presented validated UPLC method suitable for the pharmacokinetic studies and biomedical analysis of EMPA.

\section{Additional file}

Additional file 1: Fig. S1. Chromatograms obtained after using different pH values in mobile phase. Fig. S2. Chromatograms obtained after elution with mobile phase consists of; (acetonitrile: 0.1\% trifluoroacetic acid, 20:80, v/v), b) (acetonitrile: 0.1\% trifluoroacetic acid, 30:70, v/v), b) (acetonitrile: $0.1 \%$ trifluoroacetic acid, 40:60, v/v). Fig. S3. Chromatograms obtained after using different diluting solvents. Fig. S4. Chromatograms obtained after using different column temperatures.

\section{Authors' contributions}

MM participated in the study design and the results discussion and revised the manuscript. SMS participated in the study design and the results discussion and revised the manuscript. HME proposed the study design, conducted the practical work, participated in the results discussion and the preparation and writing of the manuscript. FRM participated in the results discussion, literature review, manuscript preparation and revision. All authors read and approved the final manuscript.

\section{Funding}

The authors declare that no fund was received for this study.

\section{Availability of data and materials}

All data and materials are all provided.

\section{Ethics approval and consent to participate}

The experiment was conducted according to the rules of the Ethical Committee of the Faculty of Pharmacy, Tanta University, Egypt.

\section{Competing interests}

The authors declare that they have no competing interests.

\section{Author details}

${ }^{1}$ Department of Pharmaceutical Analytical Chemistry, Faculty of Pharmacy, Tanta University, Elgeish Street, Medical Campus, Tanta 31111, Egypt. ${ }^{2}$ Pharmaceutical Services Center, Faculty of Pharmacy, Tanta University, Tanta 31111, Egypt. ${ }^{3}$ National Organization for Drug Control and Research (NODCAR), Giza 12511, Egypt.

Received: 6 March 2019 Accepted: 29 June 2019

Published online: 09 July 2019

\section{References}

1. Grempler R, Thomas L, Eckhardt Himmelsbach F, Sauer A, Sharp DE, Bakker RA, Mark M, Klein T, Eickelmann P (2012) Empagliflozin a novel selective sodium glucose cotransporter-2 (SGLT-2) inhibitor: characterisation and comparison with other SGLT-2 inhibitors. Diabetes Obes Metab 14:83-90
2. Bays H (2013) Sodium glucose co-transporter type 2 (SGLT2) inhibitors: targeting the kidney to improve glycemic control in diabetes mellitus. Diabetes Ther 4:195-220

3. Ayoub BM (2016) Development and validation of simple spectrophotometric and chemometric methods for simultaneous determination of empagliflozin and metformin: applied to recently approved pharmaceutical formulation. Spectrochim Acta A Mol Biomol Spectrosc 5:118-122

4. Ayoub BM (2016) Application of spiking technique coupled with derivative spectrophotometry for the analysis of a novel anti-diabetic combination of two co-formulated drugs with highly different concentrations. Der Pharma Chem 8:12-14

5. Padmaja N, Veerabhadram G (2016) Method development and validation of RP-HPLC method for the estimation of empagliflozin in API. Int J Pharm Sci Res 7:724-727

6. Patil SD, Amurutkar SV, Upasani CD (2016) Development and validation of stability indicating RP-HPLC method for empagliflozin. Asian J Pharm Anal 6:201-206

7. Padmaja N, Veerabhadram G (2016) Development and validation of a novel stability-indicating RP-HPLC method for the determination of empagliflozin in bulk and pharmaceutical dosage form. Int J Pharm Sci Res 7:4523-4530

8. Shyamala Nirmala K, Mounika J, Nandini B (2016) Validated stability-indicating RP-HPLC method for determination of empagliflozin. Der Pharm Lett 8:457-464

9. Jaiswal SH, Katariya MV, Katariya VR, Karva GS, Koshe K (2017) Validated stability indicating HPLC method for determination of process related impurities in empagliflozin drug substances. World J Pharm Res 6:1025-1037

10. Khalil GA, Salama I, Gomma MS, Helal MA (2018) Validated RP-HPLC method for simultaneous determination of canagliflozin, dapagliflozin, empagliflozin and metformin. Int J Pharm Chem Biol Sci 8:1-13

11. Godasu S, Sreenivas S (2017) A new validated RP-HPLC method for the determination of metformin $\mathrm{HCl}$ and empagliflozin in its bulk and pharmaceutical dosage. Int J Pharm Sci Res 6:903-917

12. Abdel-Ghany MF, Abdel-Aziz O, Ayad MF, Tadros MM (2017) New LC-UV methods for pharmaceutical analysis of novel anti-diabetic combinations. Acta Chromatogr 29:448-452

13. Syed Irfan A, Bharath Rathna Kumar P (2017) Stability indicating simultaneous estimation of metformin empagliflozin in pharmaceutical tablet dosage form by RP-HPLC. Asian J Res Chem 10:783-788

14. Ayoub BM, Mowaka Shereen (2017) LC-MS/MS determination of empagliflozin and metformin. J Chromatogr Sci 55:742-747

15. Padmaja N, Veerabhadram G (2017) A novel stability indicating RP-UPLCDAD method for determination of metformin and empagliflozin in bulk and tablet dosage form. Orient J Chem 33:1949-1958

16. Vinay Kumar D, Seshagiri Rao JVLN (2018) A new validated stability indicating RP-HPLC method for simultaneous estimation of metformin hydrochloride and empagliflozin in tablet dosage forms. IRJPMS 1:16-22

17. Ayoub BM (2015) UPLC simultaneous determination of empagliflozin, linagliptin and metformin. RSC Adv 5:95703-95709

18. Madan Mohan reddy M, Gowri Sankar D, Seshagiri Rao JVLN (2017) Stress degradation studies and development of validation stability indicating assay method by RP-HPLC for simultaneous estimation of metformin and empagliflozin in presence of degradation products as per $\mathrm{ICH}$ guidelines. J Sci Res Pharm 2:20-33

19. Donepudi Sharmila, Achanta Suneetha (2018) Validated HPLC-UV method for simultaneous estimation of linagliptin and empagliflozin in human plasma. Int J Appl Pharm 10:56-61

20. Padmaja N, Desalegn T, Sharathbabu M, Veerabhadram G (2018) New validated RP-HPLC method for the estimation of empagliflozin in human plasma. Int J Pharm Sci Res 9(11):4885-4889

21. Ayoub BM, Mowaka S, Elzanfaly ES, Ashoush N, Elmazar MM, Mousa SA (2017) Pharmacokinetic evaluation of empagliflozin in healthy egyptian volunteers using LC-MS/MS and comparison with other ethnic populations. Sci Rep 7:2583-2591

22. Thakur A, Mishra B, Mahata P (2019) Pharmaceutical impurities: a review. Int J Pharm Chem 5(7):232-239

23. Ndefo UA, Anidiobi NO, Basheer E, Eaton AT (2015) Empagliflozin (Jardiance): a novel SGLT2 inhibitor for the treatment of type-2 diabetes. Pharm Ther 40:364-368 
24. Macha S, Mattheus M, Halabi A, Pinnetti S, Woerle HJ, Broedl UC (2014) Pharmacokinetics, pharmacodynamics and safety of empagliflozin, a sodium glucose cotransporter 2 (SGLT2) inhibitor in subjects with renal impairment. Diabetes Obes Metab 16:215-222

25. Food and drug administration FDA (2001) Guidance for industry: bioanalytical method validation. US Department of Health and Human Services, Silver Spring

\section{Publisher's Note}

Springer Nature remains neutral with regard to jurisdictional claims in published maps and institutional affiliations.
Ready to submit your research? Choose BMC and benefit from:

- fast, convenient online submission

- thorough peer review by experienced researchers in your field

- rapid publication on acceptance

- support for research data, including large and complex data types

- gold Open Access which fosters wider collaboration and increased citations

- maximum visibility for your research: over 100M website views per year

At BMC, research is always in progress.

Learn more biomedcentral.com/submissions 